Littlewood, D. \& Postgate, J. R. (1957). J. gen. Microbiol. 16, 596-603

\title{
On the Osmotic Behaviour of Desulphovibrio desulphuricans
}

\author{
By DOROTHY LITTLEWOOD AND J. R. POSTGATE
}

Chemical Research Laboratory, Teddington, Middlesex

\begin{abstract}
SUMMARY: When known volumes of wet Desulphovibrio desulphuricans were suspended in standard $\mathrm{NaCl}$ solutions, the chloride was not diluted by intracellular water below $3 \%(\mathrm{w} / \mathrm{v}) \mathrm{NaCl}$; at 4 and $6 \% \mathrm{NaCl}$ exchange occurred but not to the extent observed when the organisms were made permeable with cetyltrimethylammonium chloride (CTAC). With intact organisms $\mathrm{Na}_{2} \mathrm{SO}_{4}$ up to $15 \%(\mathrm{w} / \mathrm{v})$ was not diluted by intracellular water. Dilution of 4 and $6 \% \mathrm{NaCl}$ was due to plasmolytic dehydration of organisms rather than to osmotic breakdown, since phosphate, cytochrome $c_{3}$ and $265 \mathrm{~m} \mu$.-absorbing material did not escape from the organisms, though they did with CTAC; plasmolysis was not visible microscopically. Hence these sulphate-reducing bacteria are freely permeable neither to chloride nor sulphate. Data on bacterial dimensions and fluid contents derived from this work are recorded; they compare satisfactorily with those obtained by optical measurements.
\end{abstract}

The question whether salts penetrate sulphate-reducing bacteria freely is of particular interest because their metabolism depends on the reduction of an anion. Roberts, Abelson, Cowie, Bolton \& Britten (1955) recently claimed that Escherichia coli was freely permeable to anions such as phosphate and sulphate, though this finding was disputed by Mitchell \& Moyle (1956). The present paper records a study of the osmotic behaviour of a strain of Desulphovibrio desulphuricans towards chloride and sulphate.

\section{METHODS}

Organism. A freshwater strain of Desulphovibrio desulphuricans, strain Wandle (National Collection of Industrial Bacteria, NCIB 8305) was used in this work. The strain was subcultured $(0.05 \mathrm{ml}$. into $5 \mathrm{ml}$. medium) weekly in a lactate + yeast extract + sulphate medium (medium $\mathrm{C}$ of Butlin, Adams \& Thomas, 1949) supplemented with cysteine $(5 \mu \mathrm{mole} / \mathrm{ml}$.) to poise the oxidation-reduction potential (Grossman \& Postgate, 1953a); viable counts were done in a similar medium set with agar (Grossman \& Postgate, 1953b). Organısms for work with heavy suspensions were grown in $500 \mathrm{ml}$. or 21 . flasks containing a similar medium supplemented with Tryptone (Oxoid; $0.5 \%, \mathrm{w} / \mathrm{v})$ and extra yeast extract to $0.4 \%(\mathrm{w} / \mathrm{v})$. The Tryptone was added to ensure maximum hydrogenase activity in connexion with work reported elsewhere (Littlewood \& Postgate, 1956).

Standardization of bacterial suspensions. The concentration of bacterial suspensions was determined turbidimetrically in the E.E.L. colorimeter (Evans Electroselenium Ltd., Harlow, Essex) calibrated with the Hildenborough strain of Desulphovibrio desulphuricans. 
Spectrophotometric measurements. These were made in the 'Uvispek' instrument (Hilger and Watts, London) with $1 \mathrm{~cm}$. optical cells.

Osmotic behaviour of bacteria. The 'thick suspension' technique of Mitchell \& Moyle (1956) was used to determine whether external chloride or sulphate came to osmotic equilibrium with the intracellular water. For the experiments with chloride, washed bacterial suspensions of known concentration in $\mathrm{KH}_{2} \mathrm{PO}_{4}(0 \cdot 5 \%, \mathrm{w} / \mathrm{v}, \mathrm{pH} 6 \cdot 3)$, were centrifuged in graduated conical centrifuge tubes to constant volume $(2 \mathrm{hr}$.). The supernatant fluid was discarded and each pad of packed organisms resuspended in a volume of standard $\mathrm{NaCl}$ solution equal to that of the wet mass of organisms. After re-centrifuging, the extent of dilution of the chloride in the supernatant fluid was determined analytically (see below). For the experiments with sulphate the procedure differed from this in two respects: (1) since phosphate interferes with sulphate estimation, the bacteria were suspended in sodium acetate buffer $(0 \cdot 8 \%, w / v$, pH 6.5); (2) to minimize errors due to sulphate reduction during manipulation, the suspensions were centrifuged in plastic cups at a high speed $(\mathbf{1 8 , 0 0 0} \mathbf{g})$ for $c .10 \mathrm{~min}$. The volume of organisms in each cup was calculated from the relation $\frac{\text { volume of wet bacteria }}{\text { dry weight of bacteria }}=5 \mathrm{ml}$./g. obtained in the experiments with chloride. The organisms were then resuspended in $1 \mathrm{ml}$. volumes of standard $\mathrm{Na}_{2} \mathrm{SO}_{4}$ solutions; controls with $\mathrm{NaCl}$ were run simultaneously.

The total space penetrable by ions when close-packed bacteria were made completely permeable was determined by using salt solutions containing the cetyltrimethylammonium ion, which renders the organisms permeable to small molecules (Postgate, 1956) added as the chloride (CTAC; $100 \mu \mathrm{g} . / \mathrm{mg}$. dry wt. bacteria).

Estimation of anions. Chloride was estimated by titration against $\mathrm{AgNO}_{3}$, with potassium chromate as indicator (Stockdale \& Dexter, 1938); in our hands this procedure gave a constant positive mean error of $2.49 \%$ with a standard error of $0.31 \%$. Sulphate was estimated by the method of Schroeder (1933); this procedure also gave a small mean positive error, $1 \cdot 86 \%$, with a standard error of $\mathbf{0 . 3 2} \%$. Phosphate was estimated by Fiske \& SubbaRow's method as described by Umbreit, Burris \& Stauffer (1949).

Manometry. The maximum rate of sulphate reduction at room temperature was estimated manometrically using the procedure described by Postgate (1951), except that the bacterial suspensions were pre-incubated in hydrogen for $2-3 \mathrm{hr}$. before adding the substrate.

Reagents. Analar reagents were used where available. CTAC was prepared by passing a solution of cetyltrimethylammonium bromide through the basic form of Amberlite IR-400 (British Drug Houses Ltd.). The effluent was neutralized with $\mathrm{HCl}$, frozen and evaporated to dryness; the product was refluxed with acetone, and the $\mathrm{NaCl}$ removed by filtration. After cooling, the acetone was filtered off, and the remaining traces of acetone removed by evaporation in a vacuum oven.

Optical measurements. As a check on values derived from solute penetration measurements, certain dimensions of the living bacteria were measured. 
Knaysi (1944) discussed the considerable errors inherent in optical measurements on fixed and stained cells, and similarly drying and shadowing procedures can introduce errors in measurements on electron micrographs. The dimensions recorded in this paper were therefore obtained optically under phase contrast with a micrometer eyepiece. The bacteria were grown in a liquid medium, centrifuged, set in warm agar $(1.5 \%$ ) in $0.8 \% \mathrm{NaCl}$ (to inhibit Brownian movement and motility) and slides were prepared from droplets of this agar suspension. Quoted readings are the means of ten organisms measured.

For calculating cell volumes, etc., the organisms were regarded as flatended cylinders. With this particular strain neglect of the vibrio form introduced little error, since the organisms were short, their curvature slight, and no spirilloid forms were present. This assumption would have introduced a much greater error with a more curved or spirilloid strain.

Units. Concentrations of salt solutions are expressed as $\%(\mathrm{w} / \mathrm{v})$; ionpenetrable volumes are expressed as $\%(\mathrm{v} / \mathrm{v})$ of the total volume of wet closepacked bacteria; units of cytochrome $c_{3}$ are those used by Postgate (1956).

\section{RESULTS}

Osmotic behaviour towards chloride and sulphate. The osmotic behaviour of Desulphovibrio desulphuricans stain Wandle towards chloride, investigated by the heavy suspension technique, is indicated in Table 1. In $0 \cdot 5-3 \% \mathrm{NaCl}$, the space penetrated by chloride $\left(\mathrm{V}_{\mathrm{Cr}^{\prime}}\right)$ was approximately constant; it greatly increased in $4 \%$ or more $\mathrm{NaCl}$. This suggests that $0.5-3 \%$ solutions were only diluted by intercellular water, but in $4 \%$ or stronger $\mathrm{NaCl}$ solutions the chloride ion was diluted by intracellular water as well. The value of $\mathrm{V}_{\mathrm{C}^{\prime}}$ obtained with a $\mathrm{NaCl}+\mathrm{CTAC}$ mixture equivalent in chloride to $1 \% \mathrm{NaCl}$ was higher than the highest values obtained for $\mathrm{V}_{\mathrm{Cl}^{\prime}}$ with 4 or $6 \% \mathrm{NaCl}$.

To investigate the osmotic behaviour towards sulphate, the technique was modified (see Methods). The maximum rate of sulphate reduction during centrifugation as determined by manometric controls was negligible; the figures given in Table 1 have been corrected for it. The extent of dilution of $1 \cdot 5-15 \% \quad \mathrm{Na}_{2} \mathrm{SO}_{4}$ solutions was approximately constant and equivalent to that of a $2 \% \mathrm{NaCl}$ solution, indicating that these $\mathrm{Na}_{2} \mathrm{SO}_{4}$ solutions were only diluted by intercellular water. With this modified technique higher values were obtained for the volume of intercellular water than were obtained with the earlier procedure. This is probably because the bacteria had not been centrifuged to constant volume; higher ion-penetrable volumes were also obtained using this technique when the bacteria were made permeable with CTAC, and when a control experiment was run with $\mathrm{NaCl}$ concentrations comparable to those used in the earlier experiments. This experiment gave the following results : $2 \% \mathrm{NaCl}, \mathrm{V}_{\mathrm{C}^{\prime}}=40 \cdot 4 \% ; 4 \% \mathrm{NaCl}, \mathrm{V}_{\mathrm{Cl}^{\prime}}=52.8 \% ; 6 \% \mathrm{NaCl}, \mathrm{V}_{\mathrm{Cl}^{\prime}}=58 \cdot 8 \% ;$ $\mathrm{NaCl}+\mathrm{CTAC}, \mathrm{V}_{\mathrm{Cl}^{\prime}}=\mathbf{7 3} \cdot \mathbf{4} \%$. The relationships of the values of $\mathrm{V}_{\mathrm{Cl}^{\prime}}$ agree substantially with those obtained earlier, indicating that the short duration of the experiments nevertheless allowed the organisms to reach osmotic equilibrium with chloride. 
Table 1. Apparent intercellular space in wet packed cells of Desulphovibrio desulphuricans strain Wandle

Centrifuged bacteria of measured or calculated total volume $(c .1 \mathrm{ml}$.) were suspended in known volumes of standard salt solutions, the suspensions recentrifuged and the supernatant fluids analysed for dilution of anion. The figures quoted are the space penetrated by the anion as $\%(v / v)$ of the total wet volume. The values for $\mathrm{Na}_{2} \mathrm{SO}_{4}$ are corrected for the maximum rate of sulphate reduction during the centrifuging procedure as determined by manometric controls.

Suspending fluid

\begin{tabular}{|c|c|c|c|c|c|c|c|}
\hline \multirow[b]{2}{*}{ Expt. } & \multicolumn{6}{|c|}{$\mathrm{NaCl}(\%, w / v)$} & \multirow{2}{*}{$\begin{array}{c}\mathrm{NaCl}+\mathrm{CTAC} \\
\text { (see text) }\end{array}$} \\
\hline & $0 \cdot 5$ & $\mathbf{1}$ & 2 & 3 & 4 & 6 & \\
\hline 1 & $27 \cdot 6$ & $30 \cdot 9$ & - & $27 \cdot 78$ & $46 \cdot 95$ & - & 一 \\
\hline 2 & $27 \cdot 28$ & $27 \cdot 93$ & 32 & - & $46 \cdot 06$ & - & 一 \\
\hline 3 & - & - & - & $27 \cdot 9$ & $42 \cdot 64$ & - & - \\
\hline 4 & - & - & - & $33 \cdot 61$ & $49 \cdot 95$ & - & 一 \\
\hline 5 & - & $-\cdots$ & $33 \cdot 65$ & - & $49 \cdot 7$ & $54 \cdot 76$ & $64 \cdot 06$ \\
\hline 6 & - & - & - & - & $52 \cdot 28$ & - & $65 \cdot 81$ \\
\hline
\end{tabular}

Suspending fluid

\begin{tabular}{|c|c|c|c|c|c|c|c|c|c|}
\hline \multicolumn{2}{|c|}{$\begin{array}{c}\mathrm{NaCl} \\
(\%, w / v)\end{array}$} & \multicolumn{7}{|c|}{$\mathrm{Na}_{2} \mathrm{SO}_{4}(\%, \mathrm{w} / \mathrm{v})$} & \multirow{2}{*}{$\begin{array}{c}\mathrm{Na}_{2} \mathrm{SO}_{4} \\
(3 \%)+\mathrm{CTAC} \\
(\text { see text) }\end{array}$} \\
\hline Expt. & 2 & $1 \cdot 5$ & 3 & 4 & 5 & 7 & 10 & 15 & \\
\hline 7 & $35 \cdot 9$ & $38 \cdot 2$ & $34 \cdot 76$ & $39 \cdot 44$ & - & - & - & - & - \\
\hline 8 & $37 \cdot 52$ & 38 & $40 \cdot 13$ & $40 \cdot 07$ & - & - & - & - & - \\
\hline 9 & $38 \cdot 3$ & - & $39 \cdot 07$ & - & $39 \cdot 28$ & $38 \cdot 47$ & - & - & - \\
\hline 10 & $37 \cdot 72$ & - & $37 \cdot 07$ & - & - & - & - & - & $77 \cdot 9$ \\
\hline 11 & $38 \cdot 23$ & - & $38 \cdot 8$ & - & - & - & $38 \cdot 41$ & - & $73 \cdot 83$ \\
\hline 12 & $36 \cdot 08$ & - & $34 \cdot 36$ & - & - & - & $38 \cdot 1$ & - & $74 \cdot 61$ \\
\hline 13 & 38.53 & - & $37 \cdot 45$ & - & - & - & - & $38 \cdot 2$ & - \\
\hline
\end{tabular}

Attempts to detect leakage of cellular constituents

Since 4 and $6 \% \mathrm{NaCl}$ solutions exchanged with the intracellular water of strain Wandle it was possible that breakdown of the bacterial osmotic barrier had occurred, allowing soluble constituents of the cytoplasm to leak into the medium. Osmotic breakdown of this kind is characteristic of the action of quaternary detergents (Salton, 1951; Newton, 1956). The question was investigated by seeking $(a)$ material which absorbed at $265 \mathrm{~m} \mu . ;(b)$ cytochrome $c_{3}$ (Postgate, 1956); (c) inorganic phosphate in the supernatant fluid after organisms had been treated with $\mathrm{NaCl}$ at various concentrations. Controls were run in which bacteria were treated with CTAC, known to release soluble molecules having molecular weights up to that of cytochrome $c_{3}$.

Materials absorbing at $265 \mathrm{m \mu}$. No evidence was obtained for release of material absorbing at this wavelength (Fig. 1) on treatment with $\mathrm{NaCl}$, but the experiments were not wholly conclusive because these bacteria, even after being washed four times, secreted material which absorbed at $275 \mathrm{~m} \mu$., which would mask small amounts of $265 \mathrm{~m} \mu$. material. The amount of substance absorbing at $275 \mathrm{~m} \mu$. was not related to the $\mathrm{NaCl}$ concentration, suggesting that it was not a product of osmotic leakage. The peak of absorption at $275 \mathrm{~m} \mu$. in fluid derived from CTAC-treated bacteria had the 'shoulder' at about 
$265 \mathrm{~m} \mu$. which would be expected were material absorbing at this latter wavelength released.

Cytochrome $c_{3}$. Cytochrome $c_{3}$ was sought by its strong Soret band at $419 \mathrm{~m} \mu$. when in the reduced form. It was not detected in the supernatant

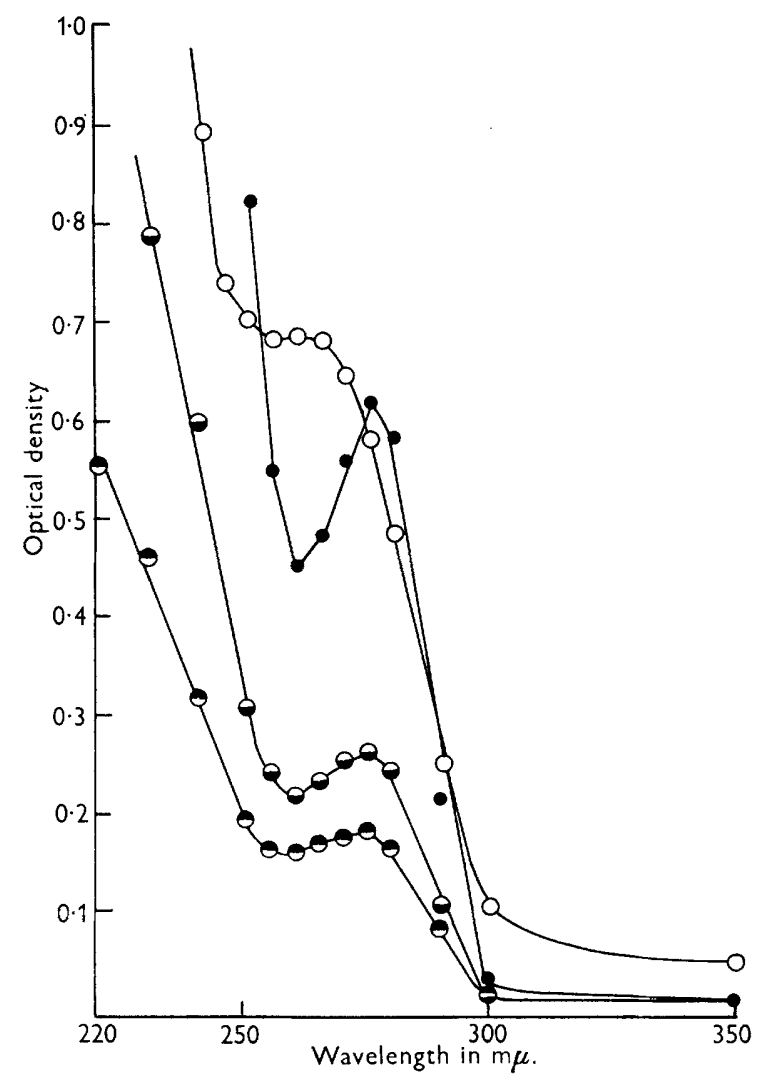

Fig. 1. Absorption spectra of supernatant fluids from Desulphovibrio desulphuricans strain Wandle treated with sodium chloride solutions. Samples of a suspension containing 5 mg. dry wt. organisms ml. were exposed to $\mathrm{NaCl}$ solutions, centrifuged, and the supernatant fluids examined for material which absorbed at $265 \mathrm{~m} \mu$. A control with cetyltrimethylammonium chloride (CTAC) was included to release all soluble cellular constituents. $\ominus, 0.8 \% \mathrm{NaCl} ; \ominus, 4 \% \mathrm{NaCl} ; \ominus, 6 \% \mathrm{NaCl} ; 0,0.8 \% \mathrm{NaCl}+100 \mu \mathrm{g}$. CTAC/mg. dry wt. organisms; total chloride $\equiv 0 \cdot 81 \% \mathrm{NaCl}$.

fluid from bacteria ( $5 \mathrm{mg}$. dry wt. $/ \mathrm{ml}$.) treated with $0.8,4$ and $6 \% \mathrm{NaCl}$; it was present in the fluid from bacteria treated with CTAC, to between $\mathbf{0 . 4 2}$ and $0.53 \mathrm{~m} \mu \mathrm{U}$. $c_{3} / \mathrm{mg}$. dry wt. organisms.

Phosphate. Small amounts of phosphate (1-1-2.6 m $\mu$ mole $\mathrm{PO}_{4} / \mathrm{mg}$. dry wt. bacteria) appeared in the supernatant fluid when bacteria, washed four times in tris-(hydroxymethyl)-aminomethane buffer $(\mathrm{pH} \mathrm{7.2)}$ were treated with $0 \cdot 8$, 4 and $6 \% \mathrm{NaCl}$; the amount of phosphate released was not related to $\mathrm{NaCl}$ concentration and was insignificant compared with the amount that appeared when organisms were treated with CTAC (17.2 m $\mu$ mole $\mathrm{PO}_{4} / \mathrm{mg}$. dry wt. bacteria). 
Attempts to observe plasmolysis. The tests described in the last section indicate that the dilution by intracellular water that took place when strain Wandle was exposed to $4 \%$ or $6 \% \mathrm{NaCl}$ did not occur by breakdown of the osmotic barrier such as that induced by CTAC; no release of intracellular constituents occurred. Hence the process must be plasmolytic, but no clear retraction of the cytoplasm could be observed under phase contrast even with $25 \% \mathrm{NaCl}$. Plasmolysis was readily observed in control experiments with some unidentified Gram-negative freshwater pseudomonads and spirilla.

Effect of $\mathrm{NaCl}$ on viability. Exposure to $6 \% \mathrm{NaCl}$ did not significantly alter the numbers of viable organisms present. A count on a suspension containing $1.2 \times 10^{9}$ viable organisms $/ \mathrm{ml} .0 \cdot 8 \% \mathrm{NaCl}$ gave a value of $1.4 \times 10^{9}$ viable organisms $/ \mathrm{ml}$. after exposure to $6 \% \mathrm{NaCl}$; CTAC reduced the viable population of a similar suspension to $7 \cdot 1 \times 10^{6}$ viable organisms $/ \mathrm{ml}$.

Bacterial volume. For comparison with the dimensions obtained from the heavy suspension experiments (see Discussion) the mean dimensions of organisms in a 3-day culture of strain Wandle were measured microscopically. The mean length was $2 \cdot 34 \mu .(\sigma=0.51 \mu$. $)$ and the mean diameter was $0.74 \mu$. $\left(\sigma=0.043 \mu\right.$.); hence the mean volume of an organism was $1.01 \mu .^{3}$.

\section{DISCUSSION}

(i) Penetration of anions. True permeability is reversible in the sense that soluble molecules can diffuse freely in and out of the organism. Except when the organisms were deliberately rendered permeable with CTAC, penetration of this kind was not detected in the experiments reported here: neither sodium sulphate nor chloride at concentrations lower than $3 \%$ became diluted with intracellular water. Since the sulphate ion is the normal respiratory substrate of these bacteria it is therefore likely either that sulphate reduction occurs outside the osmotic barrier, or that penetration of sulphate into the organism is regulated in such a manner that the ratio of the equilibrium internal concentration of sulphate ions to the external concentration is so low that the analytical procedure used in this work could not detect penetration of the ion even at high external sulphate concentrations.

Sodium chloride at 4 and $6 \%$ induced considerable dehydration of the cells, without true penetration or loss of viability, since the chloride became diluted with intracellular water. Hence a process akin to plasmolysis must have occurred though we were unable to observe it microscopically. Such dehydration did not occur even with very high concentrations of $\mathrm{Na}_{2} \mathrm{SO}_{4}$. The experiments reported here provide no explanation of this observation, which may be connected with metabolic importance of sulphate for these organisms. The impermeability of these bacteria to anions is in accord with studies by Mitchell \& Moyle (1956) on other bacteria, and contrasts with the reports of Roberts $e t$ al. (1955) that Escherichia coli is freely permeable to ions such as sulphate.

(ii) Dimensions of Desulphovibrio desulphuricans strain Wandle. The data obtained in the heavy suspension experiments can be used to calculate certain dimensions of these organisms which, when compared with optical measure- 
ments, provide a check on the validity of the technique used. The intercellular space among vibrios centrifuged to constant volume ranged from $27 \cdot 3$ to $\mathbf{3 3 . 6} \%$ of the total volume (mean $=29 \cdot 5 \%$, compare $25 \cdot 5-28 \cdot 3 \%$ obtained by Mitchell (1953) from experiments on phosphate penetration with Microcococcus pyogenes (Staphylococcus aureus), and the theoretical value of $26 \%$ calculated by Conway \& Downey (1950) for close-packed spheres). One ml. of close-packed vibrios contained $6.5 \times 10^{11}$ (total), hence the mean volume of a vibrio was $1.086 \mu .^{3}$. Microscopic measurements gave a value of $1.01 \mu .^{3}$ (Table 2). These values agree remarkably well, particularly since the microscopic measurements made no allowance for the slight curvature of the organisms, and since the heavy suspension experiments made no allowance for any solute-permeable part of the organism which might be outside the osmotic barrier. The agreement of the values confirms the opinion that the osmotic barrier to the ions studied here lies in the neighbourhood of the cell wall.

Table 2. Comparison of mean morphological dimensions of Desulphovibrio desulphuricans strain Wandle obtained by optical and heavy suspension techniques

For details of procedure see text. The organisms were regarded as straight flat-ended cylinders for volume and area calculations.

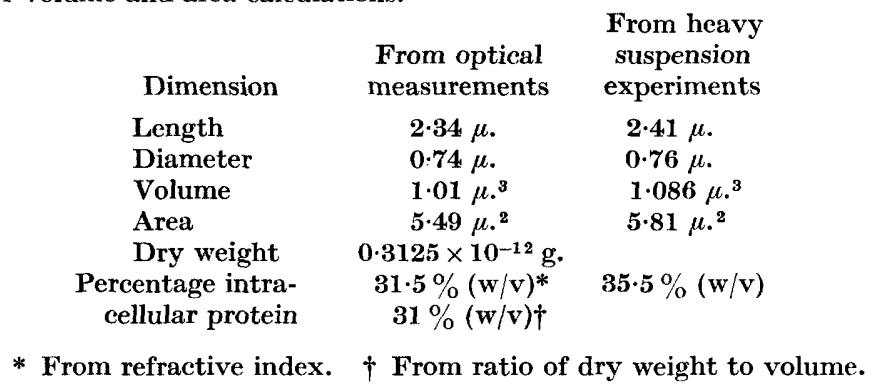

The length and diameter of the vibrios obtained from optical measurements will be subject to similar errors, but their ratio will not; when this ratio is used to calculate the mean lengths and diameter from the volume obtained in the heavy suspension experiments, the mean area of an organism can be calculated. Values for each of these quantities are quoted in Table 2.

The dry weight of a single vibrio quoted in Table 2 was obtained by dividing the dry weight of a suspension by the total count. All these figures are in the range of those recorded by Knaysi (1944) for other bacteria, and are consistent with optical measurements made by Senez (to be published) on Desulphovibrio desulphuricans strain Canet 41. Table 2 includes figures from which a further comparison can be made: organisms treated with CTAC had a mean soluteimpermeable residue of $35 \%$ of their wet volume; i.e. $50.5 \%$ of their own volume. If this residue be assumed to be protein of specific volume $\mathbf{0 . 7 1}$, then the concentration of protein in the undamaged organism should not exceed $35.5 \%(\mathrm{w} / \mathrm{v})$. Measurements of the cytoplasmic refractive index of strain Wandle in the manner used by Postgate (1956) for $D$. desulphuricans strain 
Hildenborough gave a mean value of $1 \cdot 383$, corresponding to a $31.5 \%(w / v)$ solution of plasma albumin. These values are in fair agreement considering the assumption involved, and are consistent with the value of $c .31 \%$ obtained by dividing the mean optical volume by the mean dry weight. The value of the dry weight : wet volume ratio of 5 indicates that the proportion of solid matter in the wet packed organisms was $c .20 \%(\mathrm{w} / \mathrm{v})$; Roberts et al. obtained a value of $22 \cdot 3 \%(w / v)$ from dry-weight determinations on Escherichia coli.

We are indebted to Dr P. Mitchell for valuable discussions, to our colleagues of the Microbiology Group for advice and criticism during this work, and to Dr J. C. Senez for supplying and discussing his data on the cellular dimensions of Desulphovibrio desulphuricans strain Canet 41. This paper is published by permission of the Director, Chemical Research Laboratory.

\section{REFERENCES}

Butlin, K. R., Adams, M. E. \& Thomas, M. (1949). The isolation and cultivation of sulphate-reducing bacteria. J. gen. Microbiol. 3, 46.

Conway, E. J. \& Downey, M. (1950). An outer metabolic region of the yeast cell. Biochem. J. 47, 347 .

Grossman, J. P. \& Postgate, J. R. (1953a). Cultivation of sulphate-reducing bacteria. Nature, Lond. 171, 600.

Grossman, J. P. \& Postgate, J. R. (1953b). The estimation of sulphate-reducing bacteria (D. desulphuricans). Proc. Soc. appl. Bact. 16, 1.

KnaYsi, G. (1944). Elements of Bacterial Cytology. Cornell University, U.S.A.: Comstock Publishing Co.

Littlewood, D. \& Postgate, J. R. (1956). Substrate inhibition of hydrogenase enhanced by sodium chloride. Biochim. biophys. Acta, 20, 399.

Mrtchell, P. (1953). Transport of phosphate across the surface of Micrococcus pyogenes: nature of the cell 'inorganic phosphate'. J. gen. Microbiol. 9, 273.

Mitcheld, P. \& Moyle, J. (1956). Osmotic function and structure in bacteria. In Bacterial Anatomy. Symp. Soc. gen. Microbiol. 6, 150.

Newton, B. A. (1956). The properties and mode of action of the polymyxins. Bact. Rev. $20,14$.

Postgate, J. R. (1951). The reduction of sulphur compounds by Desulphovibrio desulphuricans. J. gen. Microbiol. 5, 725.

Postgate, J. R. (1956). Cytochrome $c_{3}$ and desulphoviridin, pigments of the anaerobe Desulphovibrio desulphuricans. J. gen. Microbiol. 14, 545.

Roberts, R. B., Abrlson, P. H., Cowie, D. B., Bolton, E. T. \& Britten, R. J. (1955). Studies on Biosynthesis in Escherichia coli. Publication no. 607. Washington, D.C., U.S.A.: Carnegie Institution.

SAlton, M. R. J. (1951). The adsorption of cetyltrimethylammonium bromide by bacteria, its action in releasing cellular constituents and its bactericidal effects. J. gen. Microbiol. 5, 391.

Schroeder, W. C. (1933). Direct titration of sulphate. Industr. Engng Chem. (Anal. $), 5,403$.

Stockdale, D. \& Dexter, J. (1938). Clowes and Coleman's Quantitative Chemical Analysis, 14th ed. London: Churchill.

Umbreit, W. W., Burris, R. H. \& Stauffer, J. F. (1949). Manometric Techniques and Tissue Metabolism. Minneapolis: Burgess Publishing Co. 